\title{
Forming Critical Reading Skills in a Low-Intermediate Class of English
}

\author{
Nataliia Hromova ${ }^{1}$, Maryna Kryvych ${ }^{2}$, Nataliia Chernihivska ${ }^{2}$, Tetiana Vinnytska ${ }^{2}, \&$ Ihor Bloshchynskyi ${ }^{3}$ \\ ${ }^{1}$ Taras Shevchenko National University of Kyiv, Ukraine \\ ${ }^{2}$ National Academy of Security Service of Ukraine, Kyiv, Ukraine \\ ${ }^{3}$ Bohdan Khmelnytskyi National Academy of the State Border Guard Service of Ukraine, Khmelnytskyi, Ukraine \\ Correspondence: Ihor Bloshchynskyi, Bohdan Khmelnytskyi National Academy of the State Border Guard Service \\ of Ukraine, Khmelnytskyi, Ukraine.
}

Received: November 1, 2021

Accepted: November 30, $2021 \quad$ Online Published: December 10, 2021

doi:10.5430/wjel.v12n1p74

URL: https://doi.org/10.5430/wjel.v12n1p74

\begin{abstract}
Critical reading skills constitute an important part of an independent critical reader and are often formed in advanced-level students. It is argued that low-level learners of English also need to get acquainted with the basics of critical reading in the first years of their tertiary education. The aim of this study is to define a range of critical reading elements the low intermediate EFL students can demonstrate within a three-month period of critical reading instruction. The experiment on establishing the students' attitude to critical reading and defining their critical reading abilities while commenting on texts was conducted. The findings of the questionnaire showed the participants' attitude to critical reading as the way to question and disagree with the author's opinion rather than to analyze information. The participants considered themselves quite competent in critical reading but did not see the practical use of applying these skills. A three-month critical reading intervention was introduced and followed by writing final commentaries upon the given text. The survey after the intervention found that the students of the experimental group showed the ability to justify their judgments by supporting claims while commenting upon the given texts. They could also express disagreement with the opinion in the text more often than before the intervention. In the control group, the prevailing agreements with the author's viewpoint in the commentaries rarely followed by justifications showed the students' unwillingness to create new ideas and proved their passive roles in dealing with information. Thus, according to the experiment results, the range of critical reading strategies the low intermediate class demonstrated included expressing judgments and supporting claims, finding different points of view on the problem in the text, and expressing disagreement with the given opinion. The amount of irrelevant information the participants mentioned in their commentaries proved the necessity for further interventions in order to engender their critical literacy.
\end{abstract}

Keywords: comprehension, critical reading skills, intervention, literacy, text

\section{Introduction}

It is of the greatest importance that students have and use their critical reading skills for efficient comprehension of the texts they read during and beyond their academic studies. Forming critical reading skills has been a popular research issue in the field of reading instruction and teaching languages for many decades. And it is still considered to be relevant for many scientists struggling to design efficient methods to develop their students' critical minds and transform passive learners into critical thinkers.

Most researchers claim to achieve good results after having implemented special intervention programs in their reading classes (Larking, 2017; Mateos, Rijlaarsdam, Martín, Cuevas, Van den Bergh \& Solari, 2020; Wallace, 2003). The vast majority of their students are English native speakers or represent advanced or upper-intermediate learners of English as a foreign language (EFL college students). Thus, there arises a question of a necessary level of mastering a language to start implementing critical literacy in classes. If the students' level of English is low intermediate, is there a possibility to develop their critical minds? Perhaps it would be more efficient to introduce the basics of critical literacy into high school classes gradually increasing their complexity and ensuring a smooth transition to undergraduate programs at university rather than designing accelerated critical reading interventions for tertiary students?

Some researchers agree with the ideas that they should not expect too much from their students in the first years of Published by Sciedu Press 
teaching critical reading as it takes quite a long time to overcome students' conformity and unwillingness to question the given ideas and constructing the new ones. Thus, there appears a huge gap between teachers' expectations and their students' abilities (Bosley, 2008; Bury, 2011; Dubicki, 2013). Thinking outside the box requires independence and courage which need to be supported by creating effective learning environment in class (Brevik, 2019; Kadir, Subki, Jamal \& Ismail, 2014; Larking, 2017).

Traditional teaching English contributes to students becoming submissive readers as they get used to comprehension-based reading strategies, completing vocabulary tasks and answering factual questions without challenging given ideas. Wallace (2003) suggested three approaches to text selection and creating reading tasks which are worth considering for critical reading skills development. The author insists on making students aware of the culture-specific content of the given texts and fostering their active readers' standpoints to question the socially accepted opinions about people and events in the texts thus encouraging their alternative reading.

Kadir, et al. (2014) call for a thorough selection of texts for reading which involves problem-solving components and culture-based content of the material. Students should be able to find contradictions and alternative views on the problem in texts. Dividing tasks into three main groups: pre-reading, while-reading, and post-reading allows critical tasks to appear in a logical way. The first stage should contain hypothetical questions to brainstorm students' ideas and create interest in the problem in the text. During the second stage, while-reading, students may consider the author's role and intention, analyze one or more discourses and find different points of view. In the post-reading tasks, they could assess the way the problem is described in the text and consider other possible ways to do it.

In their turn, Sutherland and Incera (2021) suggest a range of activities or behaviors students should practice in order to develop critical reading attitude: previewing, reviewing, summarizing, elaborating, synthesizing, and applying. Previewing suggests skimming reading, asking anticipating questions about the text, scrutinizing the title, images and publishing data of the text, guessing the purpose of the text. Meantime the authors refer to the findings of Strukelj and Nehoster (2018) who established that skimming the text may lead to worse comprehension results compared to thorough reading because the students focus on looking for the answer to the given questions rather than trying to embrace the idea of the text.

Reviewing involves reading the text for several times, both silently and aloud, in order to have a deeper understanding of different ideas in the text. Being the basic reading strategies, silent and aloud readings are argued to be essential in the initial stages of teaching students critical reading (Brevik, 2019). They can be followed by underlying and highlighting phrases and ideas, circling or note-taking while reading. In the research conducted by Slotte and Lonka (1999) the quality of note-taking affected the students' performance in an experiment where students were allowed to review their own notes before writing essays. Those who summarized the content of the information performed better than those who took verbatim notes. However, the quality of students' inferences did not suffer significant improvements due to note-taking practice.

By summarizing the text students practice different activities which include generating key vocabulary, paraphrasing, organizing information in charts, tables, schemes and other visual techniques. Elaborating the text involves the ability to bridge the students' previous experience with the information in the given text. The typical tasks to elaborate texts are the following: discussing the problem of the text, answering dialogical questions, "talking" to the author of the text, writing annotations. Discussions in groups foster generating new ideas but do not influence the students' ability to combine various ideas. To perform synthesizing activities, students need explicit instruction from the teacher (Mateos et al., 2020). As synthesizing is one of the high-level skills in critical reading, it involves comparison of different sources of information, finding contrasting ideas, and questioning conclusions in the text. Specific interventions are needed to teach students to deal with conflicting ideas and problems in the text (Mateos et al., 2020). One more skill which Sutherland and Incera (2021) mention in their research is applying information from the text in new contexts. The students should know how to implement the ideas in a new way, how to solve new problems using the previous knowledge from the text, and how to detect common features in different situations (Sutherland \& Incera, 2021). Some scholars Soloviova, Bloshchynskyi, Tsviak, Voitiuk \& Mysechko (2021) emphasized that while reading fairy tales readers can understand non-physical things on the basis of their own actions and characteristics. For example, viewing something as abstract as 'happiness' in human terms has a descriptive and explanatory power in the way that makes sense to readers.

Larking (2017) organized critical reading and comprehension-based reading strategies for EFL learners into two lists and after having conducted a survey established that comprehension-based reading strategies were used more frequently at colleges. The critical reading strategies included the following items: distinguishing main and supporting ideas, evaluating the credibility of the claims, making relevant inferences about the text, making 
judgments about how the text is argued, questioning the author's assumptions, deciding how to use the text for the students' own study, identifying rhetorical devices, identifying power relations, evaluating the quality of the text, and distinguishing between fact and opinion. The strategies aimed at constructing ideas rather than criticism involved the following items: previewing a text, scanning a text for specific information, recognizing topics in the text, locating topic sentences, guessing the meaning of unknown words from the context, skimming a text for the gist of the text, paraphrasing parts of a text in other words, reading faster by reading phrases rather that separate words, rereading a text for deeper comprehension, understanding the relationship of ideas by recognizing the structure of a text.

Some researchers consider that undergraduate students are not reading as many books, newspapers, and magazines as they used to before. However, their reading preferences have shifted to reading blogs, posts, e-news which leads to a problem of quality reading. Most information the students "consume" is low-quality messages and texts written by non-professional writers, journalists willing to draw the readers' attention by any means, and anyone who wants to express their views. Thus, these texts contain a lot of grammar and lexical mistakes, their syntactic structure is incorrect, and they are overloaded with colloquial language. Being too simplified in vocabulary and grammar, abundant in bright images and animation, these texts do not foster thorough comprehension, that is why we can call the process of receiving information "consuming" rather than reading it. (Cullinan, 2000; Hoeft, 2012).

Main discrepancies between a commonly accepted idea of the importance of critical reading skills and the reality where students are still lacking them lie in the poor instruction from teachers and occasional interventions aimed at developing certain critical reading skills without applying a holistic approach (Afanasieva, Fedotova \& Smirnova, 2020; Larking, 2017).

As critical reading skills are relevant not only for the mother tongue but also for reading in English as a foreign language, it is suggested that there is a necessity to develop them even in a low-intermediate EFL class. Thus, the purpose of this study is to define a range of critical reading elements the low intermediate EFL students can demonstrate within three months of critical reading instruction. The main tasks were the following: 1) to define the students' understanding of the role of critical reading for learning and critical reading skills for successful academic performance; 2) to conduct the experiment on the students' ability of critical reading before and after the intervention; 3 ) to compare the number of critical elements in the written text commentaries in the control and experimental groups before and after the intervention.

\section{Method.}

Participants. The survey involved 48 first-year Choreography students: 7 males (15\%) and 41 females (85\%) in Borys Grinchenko Kyiv University and covered March-May 2021 period. The students' background information included their age, gender and experience in learning English. The majority of students were 18 years old (65\%) and the rest of them 17 years old (35\%). Most students' background in learning English was over 10 years (87\%), with the rest of respondents having 6-10 years of experience (13\%). The participants' level of English was defined on completion of the on-line General English Test from Cambridge Assessment English site. 89\% of students were assessed as low-intermediate and $11 \%$ as intermediate learners.

Research Ethics. The authors state no conflict of interest.

Materials. The research involved three main instruments: 1) the students' written responses on their understanding of the role of critical reading for learning, 2) the questionnaire adapted from the surveys by Afanasieva et al. (2020) and Gorzycki, Howard, Allen, Desa \& Rosegard (2015) in order to identify the importance of critical reading skills for successful academic performance at university, and 3) the students written commentaries on the texts before and after the intervention.

Procedure. The first stage of the survey consisted of the students' assessment of the role of critical reading for learning. They had to write their answers to the questions: 1) "What is critical reading?" and 2) "What is the role of critical reading skills in the learning process?" The purpose of the task was to find out how the students understood the meaning of critical reading and what they thought of the practical use of critical reading skills for their learning performance. The survey was conducted in class time and had a 100 per cent return rate. The participants were allowed to respond in either English or Ukrainian to put them at ease.

The task lasted 20 minutes and the majority of students chose to respond in Ukrainian. Their responses were collected for a qualitative data analysis based on the grounded theory with an application of an inductive approach. After a detailed and thorough revision several codes concerning the idea of critical reading and the role of critical reading skills in the learning process were identified. To prove the validity of the study the panel of three experts and associate professors selected from university teachers of English were involved to review the codes and after a series 
of discussions the codes were organized in order to generate the themes for the first and the second questions.

At the following stage the students were asked to complete a questionnaire on their self-assessment of their critical reading skills. The questionnaire consisted of 7 statements which the students had to agree or disagree with according to a 5-point Likert-type scale by putting 5 in case they strongly agreed, 4 - partly agreed, 3 - equally agreed and disagreed, 2 - partly disagreed and 1 - strongly disagreed. The data were analysed using the SPSS program and the scale demonstrated the level of agreement and disagreement with the items in the questionnaire and interpreted according to the following criteria designed by the authors of this survey: 3.5 - 5.0 mean high degree of confidence, $2.0-3.4$ - moderate degree, and $0-1.9$ - low degree of the students' confidence in their critical reading skills. The survey was administered in English at the class of English with the test administrator present to help with difficulties in understanding the items. The participants were given 15 minutes to complete the test.

The third stage of the experiment aimed at defining the type of critical reading skills the students were able to apply while reading texts. The participants were divided into two groups: control (23 students) and experimental (25 students), and given a text in English to comment upon while reading. The text dealt with advantages of living in the city and was structured as 10 numbered paragraphs which the students had to write commentaries upon each paragraph. The choice of the task was justified by the findings about writing notes and commentaries to the text as one of the most effective tasks to develop critical reading skills (Tomitch, 2000; Khamkhong, 2018; Rohmad, 2018). In addition, this task gave the students certain freedom in their responses, and thus, it did not affect their opinions. The responses were assessed by the following criteria: 1) critical reading elements, 2) the students' opinions agreeing and disagreeing with the author of the text, and 3) irrelevant ideas the students gave while completing this task. The amount of statements meeting these criteria was counted in each commentary.

The critical reading elements the students' responses were expected to contain involved: 1) expressing judgments, 2) providing supporting claims, 3) providing different points of view on the problem, 4) asking the author dialogical questions, and 5) analysing the text. Separately there were counted a number of agreements and disagreements with the author of the text which the students expressed in their commentaries. The purpose of this survey was to reveal if the students preferred having a conformity standpoint and agreed with the suggested opinion in the text rather than presenting their own and defending its reasons. Conformity is considered an easy way to avoid creating one's own opinion so its presence in the commentaries would prove the students' inability or unwillingness to think critically. The presence of irrelevant information, such as too abstract statements and statements distracted from the main idea would show that the participants are unaware of what critical reading skills represent.

After receiving the results of the first commentaries, the instructor introduced a specially designed critical reading training into the traditional course of English for the experimental group and lasted for three months. The instruction program included several critical reading strategies from $M$. Larking's survey and adapted to meet the low-intermediate students' abilities (Larking, 2017). The students learned how to define the main idea of the text, find the supporting claims, state the purpose of the text and predict the intentions of the author. Special attention was paid to the dialogical interaction with the text where the participants practiced asking clarifying questions, questions-doubts, anticipating and practical questions. The total amount of texts which were used to form critical reading skills was 14 and covered the topics according to the syllabus: the city life, shopping, arts, work and study, and learning foreign languages.

The control group did not receive any additional instruction for forming critical reading skills. Its students completed traditional reading tasks on vocabulary and general text comprehension which involved fact questions, true/false questions, and tasks to explain the meaning of some words in the texts.

At the final stage of the experiment the students of both groups received a final text about the English language and the ways to learn it to comment upon. The purpose of this task was to see the expected difference between commentaries of students in both groups in terms of containing critical reading elements.

\section{Results}

The qualitative analysis results. This section contains the students' assessment of the role of critical reading for learning. Three themes were generated for the first question: 'criticism', 'thorough reading', and 'thoughtful reading' and three themes for the second one: 'to disagree', 'to evaluate', and 'to foster consideration' (Table 1). 
Table 1. Themes and codes for the meaning of critical reading

\begin{tabular}{ccc}
\hline \multicolumn{1}{c}{ Criticism (31) } & Themes and Codes & Thoughtful reading (12) \\
\hline Criticism of the author's ideas (19) & Finding answers to the questions (11) & Establishing the author's intention (6) \\
Disagreement with the author's ideas (9) & Finding details in the text (3) & Establishing the main idea of the text \\
Finding mistakes and wrong statements & Finding opposite viewpoints (3) & (2) \\
& & Thinking while reading (2) \\
& Working on the text (2) & Discussing the problem of the text (2) \\
\hline
\end{tabular}

Criticism. Most students believed that critical reading implied criticizing in the sense of disagreeing with the given opinion or the act in the text. They associated criticism with finding weak points in the author's standpoint ("Critical reading means finding what the author said incorrectly"). The students were inclined to find the wrong statements in the text rather than develop a dialogical communication with the author ("Critical reading intends to criticize the author, disagree with his or her ideas and find counter-arguments"). The desire to challenge the given facts in the text transformed in the learners' minds into the desire to correct and contradict the author of the text ("The idea of critical reading is to find mistakes and wrong information in the text, correct them and give the right opinion to the problem").

Thorough reading. Some participants viewed critical reading as detailed thorough reading and elaboration of the text. Traditional strategies of dealing with texts and doing reading tests developed in students a habit of looking for answers to the questions or scanning the text for specific details. They dwelled on the idea of "reading to find and remember all the necessary details in order to answer the questions to the text". A small part of learners argued that critical reading aimed at finding opposing viewpoints ("It means reading thoroughly and finding opposite opinions") but no one explained the reason of looking for them. A few students thought that reading critically involved thorough research for grammar and key vocabulary necessary to complete the following lexical tasks ("Critical reading means working on the text and translate it in order to be able to do the after-reading tasks").

Thoughtful reading. A small number of participants were of the opinion that critical reading involved thinking while reading and taking into account the author's presence in the text ("Every text is written by the author who wanted to believe him or her. So critical reading means establishing that author's purpose and intentions"). Some students mentioned studying the text to define its main idea and supporting arguments ("If reading the text is critical, it means careful and thoughtful reading in order to state its main idea and be able to support it with facts and statements form the text"). Two students called critical reading "thinking while reading" and other two students suggested "being able to conduct discussions upon the problem in the text".

The results of the content analysis of the students' answers to the second question ("What is the role of critical reading skills in the learning process?") are shown in Table 2.

Table 2. Themes and codes for the role of critical reading skills in the learning process

\begin{tabular}{|c|c|c|}
\hline To disagree (41) & $\begin{array}{l}\text { Themes and Codes } \\
\text { To evaluate (27) }\end{array}$ & To foster consideration (13) \\
\hline To criticize the given opinion (21) & To be able to evaluate ideas (12) & $\begin{array}{l}\text { To make students reconsider the ideas } \\
\text { (10) }\end{array}$ \\
\hline To disagree with the given opinion (15) & To find relative facts (11) & $\begin{array}{c}\text { To make students think before making } \\
\text { suggestions ( } 3 \text { ) }\end{array}$ \\
\hline To find information to disagree with (5) & To determine important information (4) & \\
\hline
\end{tabular}

To disagree. As seen from Table 2 the participants mainly associate critical skills with the ability to contradict and disagree with the given opinion. They clearly state that "students have to develop critical reading skills in order to criticize the opinion in the text and find arguments to persuade others in a different idea". Criticism is interpreted as finding disadvantages in the given text and defending the opposite opinion ("I think that critical reading skills can help me find the right way to contradict the writer's opinion", "the role of these skills is to check the facts and find the incorrect ones"). Thus, the main focus was given to looking for misleading or wrong ideas with their compulsory refutation.

To evaluate. Some students considered critical reading skills as abilities to assess and evaluate viewpoints and facts ("I can use my critical reading skills to compare the facts in the text and evaluate their importance"). Others interpret them as abilities to define relative and important facts ("I can use my critical skills to differentiate important and relative information from irrelevant one and to be able to work with the text", "One of the tasks the teachers give 
us is to write a plan or a summary of the text. So critical reading skills will help us to determine important information and complete these tasks").

To foster consideration. 13 students decided that critical reading skills encourage thorough consideration on the problem in the text with the possibility to change their mind ("Sometimes one reading does not give the true picture of the problem in the text. Students have to read the text again and try to think about the situation, take into account all the factors and maybe they will change their first opinion"). The participants of the survey believed that their thinking process caused by a critical way of reading texts could make the following discussion more effective and justified ("Before making any suggestions and conclusions you need to think about the problem in the text from different points of view. If you read the text critically, you notice all the necessary facts and can explain the reasons and motives of the problem, so you can discuss the text with your partner efficiently").

A self-assessment survey results. The survey attempted to examine how confident the participants were in possessing critical reading skills and what role they assume to these skills for the successful academic performance. The results of the Likert-type questionnaire are shown in Table 3.

Table 3. A survey of students' self-assessment of their critical reading skills

\begin{tabular}{|c|c|c|c|c|c|}
\hline № & Items & $\mathbf{N}$ & Mean & SD & $\begin{array}{c}\text { Rating of } \\
\text { confidence } \\
\text { level }\end{array}$ \\
\hline 1 & I fully understand what critical reading is. & 48 & 4,0 & 1 & High \\
\hline 2 & I have strong critical reading skills. & 48 & 2,6 & 1,6 & Moderate \\
\hline 3 & I use critical reading strategies in my everyday learning. & 48 & 3,0 & 1,3 & Moderate \\
\hline 4 & $\begin{array}{l}\text { I believe that critical reading strategies can make my } \\
\text { learning at the university efficient. }\end{array}$ & 48 & 2,9 & 0,5 & Moderate \\
\hline 5 & $\begin{array}{l}\text { My teachers consistently and explicitly teach students } \\
\text { how to read critically. }\end{array}$ & 48 & 2,8 & 1,2 & Moderate \\
\hline 6 & $\begin{array}{l}\text { Students can learn what they need to learn without using } \\
\text { their critical reading skills. }\end{array}$ & 48 & 3,2 & 1,3 & Moderate \\
\hline 7 & $\begin{array}{l}\text { I would appreciate it if instructors teach us critical } \\
\text { reading skills. }\end{array}$ & 48 & 3,4 & 1,4 & Moderate \\
\hline
\end{tabular}

The students' responses to Item 1 (I fully understand what critical reading is) showed a high level their confidence with the average mean 4,0, while responses to other statements had moderate means with the last Item 7 (I would appreciate it if instructors teach us critical reading skills) results bordering with high level of confidence $(3,4)$.

At the third stage of the experiment the students divided into two groups - control and experimental - commented upon the given text in writing. The results are shown in Table 4.

Table 4. The students' commentaries contents before the critical reading instruction

\begin{tabular}{|c|c|c|c|c|c|c|c|c|}
\hline & \multicolumn{5}{|c|}{ Critical reading elements } & \multicolumn{2}{|c|}{ Agreement } & \multirow{2}{*}{$\begin{array}{l}\text { Irrelevant } \\
\text { information }\end{array}$} \\
\hline & 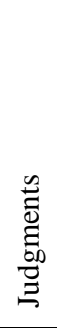 & 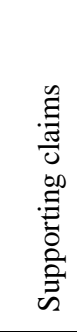 & 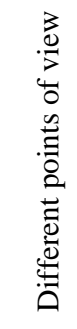 & 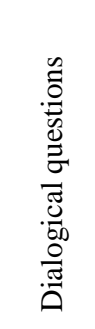 & 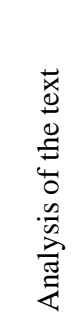 & 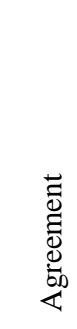 & 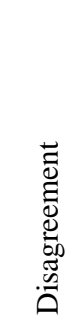 & \\
\hline Control group & 17 & 8 & 5 & 2 & 2 & 58 & 13 & 21 \\
\hline $\begin{array}{l}\text { Experimental } \\
\text { group }\end{array}$ & 11 & 9 & 6 & 1 & 1 & 54 & 14 & 24 \\
\hline
\end{tabular}

As it can be seen from the results, both groups of participants preferred to agree with the author (58 statements of agreement in the control group and 54 statements of agreement in the experimental group). Taking into account the fact that the text dealt with 10 advantages of living in the big city and the students were expected to comment upon each of them $8 \%$ of written works contained from 0 to 3 commentaries. The majority of students' statements 
contained consent without any supporting claims ("Yes, I completely agree that there are many places in the city where you can have a good time", "I agree with every word in this text"). Occasionally students expressed their own judgments but still lacked any reasons to explain their opinions ("Yes it's cool, but I think it can be dangerous", "Sometimes people underestimate the subway"). Some students got distracted from the problem in the text and used the given space for commentaries as the place for the translation of difficult words or wrote about their own experience which led them away from the issue under the discussion ("This text is also true. For example, I have lived all my life in a big city and have not tried everything during this time, but to be honest, I am not very interested in being here, and there is no motivation to do something"). Such responses were considered as irrelevant information and appeared in both control and experimental groups commentaries (21 and 24 answers respectively). The least popular activity appeared to ask dialogical questions ( 2 in the control group and 1 in the experimental group).

After the three-month period of critical reading instruction which involved 14 texts the students of both groups were given the final task to comment upon the text about the ways to learn English. The text consisted of 5 numbered paragraphs which the participants were expected to read critically and write their commentaries on. The results of the final task are shown in Table 5.

Table 5. The students' commentaries contents after the critical reading instruction

\begin{tabular}{|c|c|c|c|c|c|c|c|c|}
\hline & \multicolumn{5}{|c|}{ Critical reading elements } & \multicolumn{2}{|c|}{ Agreement } & \multirow{2}{*}{$\begin{array}{l}\text { Irrelevant } \\
\text { information }\end{array}$} \\
\hline & 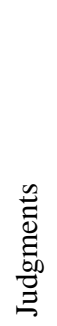 & 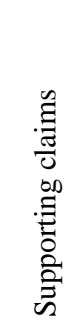 & 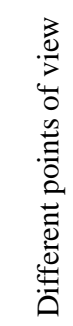 & 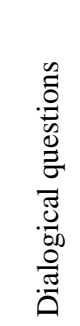 & 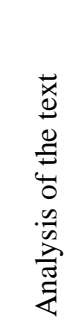 & 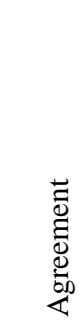 & 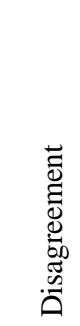 & \\
\hline Control group & 20 & 7 & 4 & 0 & 2 & 52 & 10 & 18 \\
\hline $\begin{array}{l}\text { Experimental } \\
\text { group }\end{array}$ & 27 & 24 & 13 & 2 & 3 & 33 & 35 & 12 \\
\hline
\end{tabular}

The results of the survey proved that critical reading instruction significantly changed the experimental group students' critical attitude to the texts and created the gap between the ways the students from both groups approached reading information. The students expressed their judgments on the problem of the text but the experimental group participants supported their opinion with arguments ( 24 statements) ("The fear of mistakes can stop many people from learning something new. However, I'm convinced that everyone can always find a training format that will reveal the abilities and will be comfortable and useful special for you. You can practice in a group, with a tutor or online-choose your way and forget about fears") while most students from the control group chose to state the idea without any justification or support ("For me, thinking in English is the most difficult, it is still difficult for me to understand how it is, but I hope that with constant practice I will be able to learn"). Only 7 statements of supporting claims were found in the control group students' works. The students from the experimental group presented different points of view 13 times while the students from the control group managed to find them only 4 times. Dialogical questions which could show the participants' thinking process were mentioned only twice in the experimental group ("Certainly these are the general advantages of knowing foreign languages. However, I think, that it's more effective for everyone to form their own list of language learning benefits. It's really important to honestly answer the question "Why should I do this? What do I want to achieve?"), but no one in the control group chose to ask them. The analysis of the text was present 2 times in the control group students' works and 3 times in the experimental group works. Meantime the findings demonstrated the rise in the amount of disagreements the experimental group students expressed (35) compared to agreements (33). The majority of students tried to explain their choice ("Thinking in English is a very strange idea. How can you think in another language when you just started learning it? Thinking about English - yes. But thinking in English is only possible when you know this language perfectly"). The control group students preferred to agree with the given statements in the text both with and without explaining their opinion ("I completely agree with this opinion! Making mistakes is normal. Now my level of English is not very good. I often say words incorrectly. And this is 
normal, because I study. I believe that if you do not make mistakes, you will not develop. Mistakes are part of the learning process to help you become better", "I totally agree with that, you should always be motivated"). The number of irrelevant items was still high in both groups (18 in the control group and 12 in the experimental one). Some commentaries looked too generalized and abstract ("Motivation is one of the main aspects in any field of activity. If you do not have motivation, then you will not be able to do anything efficiently") or too categorical ("Only mistakes really teach and provide a useful experience").

\section{Discussion}

The findings of the survey proved the dominance of comprehension rather than critical literacy in most students' works which goes in line with Larking's survey (2017). The main idea of critical reading which the participants reported was criticism and the students saw the role of critical reading skills in challenging and disagreeing with the author of the given opinion in the text.

The participants considered themselves quite competent in critical reading but they were not able to see the practical use of applying these skills so they believed that they could succeed without them. The moderate level of confidence the students demonstrated concerning the effectiveness of their critical reading skills for the successful academic performance and supported by the idea that students could learn what they needed to learn without using their critical reading skills was inconsistent with their initial claim to understand the meaning of critical reading. In their first commentaries, the students demonstrated the lack of basic critical reading elements and repeatedly returned to expressing agreements with the author as the way to avoid making their own judgments. In cases of disagreeing with the given viewpoints, most participants did not provide any reasons or explanations to support their opinions. In addition, their commentaries frequently contained irrelevant or generalized information which proved the students' inability to act as critical readers. After the period of special instruction, the expected difference in the students' manner of reading was noticed in the results of a final commentary. The students of the experimental group demonstrated more critical engagement, such as making judgments, supporting their viewpoints and finding different and often contradicting opinions in the text while the control group students' works were still lacking these elements. The experimental group students started to disagree with the author more often which showed their readiness to create their own vision of the problem, analyzing it and suggesting reasons to prove new ideas. Nevertheless, irrelevant, too abstract statements and statements distracted from the main idea still remained widely present in students' commentaries of both groups which reflected the necessity of a longer period of training in order to obtain more sustainable results in forming critical reading skills.

\section{Conclusion}

Assuming that critical literacy is essential for advanced EFL college students to deal with fake and misleading information, it is argued that low-level learners of English also need to get acquainted with the basics of critical reading from the first years of their tertiary education or even earlier, in their high school classes. More explicit instruction from the lecturer can facilitate the transition from comprehension-based reading attitudes to critical reading students' behavior. Introducing critical reading instruction for low intermediate EFL class fosters students to construct ideas rather than consuming big amount of information. The results of the survey showed that although it is essential for more advanced proficiency EFL students to engender their critical literacy, low intermediate students also demonstrated their ability to develop a critical approach to different literary sources. The amount of irrelevant ideas still present in the students' written works proved the necessity for further critical reading interventions. Critical reading instruction must be designed thoroughly and implemented in last high school or first university years of studies with a gradual transition from a comprehension focus to a more interactive model to ensure forming students' minds to become independent critical readers. This study results indicate the need for longitudinal research to follow up on the dynamics and effects of forming critical reading skills on students' becoming independent critical readers and thinkers.

\section{References}

Afanasieva, O., Fedotova, M., \& Smirnova, M. (2020). Coherence of critical reading skills and teacher training development. Revista Espacios, 41(46), 92-101. https://doi.org/10.48082/espacios-a20v41n46p09

Bosley, L. (2008). "I don't teach reading": Critical reading instruction in composition courses. Literacy Research and Instruction, 47(4), 285-308. https://doi.org/10.1080/19388070802332861

Brevik, L. M. (2019). Explicit reading strategy instruction or daily use of strategies? Studying the teaching of reading comprehension through naturalistic classroom observation in English L2. Reading and Writing, 32(9), 2281-2310. https://doi.org/10.1007/s11145-019-09951-w 
Bury, S. (2011). Faculty attitudes, perceptions and experiences of information literacy: A study across multiple disciplines at York University, Canada. Journal of Information Literacy, 5(1), 45-64. https://doi.org/10.11645/5.1.1513

Cullinan, B. E. (2000). Independent reading and school achievement. School library media research. Research journal of the American Association of School Librarians, 3. Retrieved from https://www.ala.org/aasl/sites/ala.org.aasl/files/content/aaslpubsandjournals/slr/vol3/SLMR_IndependentReadin g_V3.pdf

Dubicki, E. (2013). Faculty perceptions of students' information literacy skills competencies. Journal of Information Literacy, 7(2), 97-125. https://doi.org/10.11645/7.2.1852

Gorzycki, M., Howard, P., Allen, D., Desa, G., \& Rosegard, E. (2015). Undergraduate critical reading performance: A Summary of 848 Reading Tests. Retrieved from https://senate.sfsu.edu/sites/default/files/Summary\%20in\%20Six\%20Pages.pdf

Hoeft, M. E. (2012). Why university students don't read: what professors can do to increase compliance. International journal for the scholarship of teaching and learning, 6(2). https://doi.org/10.20429/ijsotl.2012.060212

Kadir, N., Subki, R., Jamal, F, \& Ismail, J. (2014). The importance of teaching critical reading skills in a Malaysian reading classroom. The 2014 WEI International Academic Conference Proceedings. Bali, Indonesia, 208-219. Retrieved from https://www.westeastinstitute.com/wp-content/uploads/2014/06/Norbaiyah-Abd-Kadir-Full-Paper.pdf

Khamkhong, S. (2018). Developing English L2 critical reading and thinking skills through the Pisa reading literacy assessment framework: A case study of Thai EFL learners. 3L: The Southeast Asian Journal of English Language Studies, 24(3), 83-94. https://doi.org/10.17576/3L-2018-2403-07

Larking, M. (2017). Critical reading strategies in an advanced English classroom. APU Journal of Language Research, 2, 50-68. Retrieved from https://core.ac.uk/download/pdf/84116459.pdf

Mateos, M., Rijlaarsdam, G., Martín, E., Cuevas, I., Van den Bergh, H., \& Solari, M. (2020). Learning paths in synthesis writing: which learning path contributes most to which learning 0utcome? Instructional Science, 48, 137-157. https://doi.org/10.1007/s11251-020-09508-3

Rohmah, G. N. (2018). Critical reading: students' problems, strategies, and reflections. Journal of English Language Literature and Teaching, 2(1), 21-26. https://doi.org/10.17977/um046v2i1p20-24

Slotte, V., \& Lonka, K. (1999). Review and process effects of spontaneous note-taking on text comprehension. Contemporary Educational Psychology, 24(1), 1-20. https://doi.org/10.1006/ceps.1998.0980

Soloviova, O., Bloshchynskyi, I., Tsviak, L., Voitiuk, O., \& Mysechko, O. (2021). Compatibility of semantics of suffixes with gender assignment in Old English. International Journal of English Language and Literature Studies, 10(3), 224-235. https://doi.org/10.18488/journal.23.2021.103.224.235

Strukelj, A., \& Niehorster, D. (2018). One page of text: eye movements during regular and thorough reading, skimming, and spell checking. Journal of Eye Movement Research, 11(1), 1-22. https://doi.org/10.16910/jemr.11.1.1

Sutherland, A., \& Incera, S. (2021). Critical reading: what do faculty think students should do? Journal of College Reading and Learning, 51(4), 267-290. https://doi.org/10.1080/10790195.2021.1887777

Tomitch, L. (2000). Designing reading tasks to foster critical thinking. Ilha do Desterro A Journal of English Language Literatures in English and Cultural Studies, 38, 83-90. Retrieved from https://periodicos.ufsc.br/index.php/desterro/article/view/8260/765

Wallace, C. (2003). Critical reading in language education. London: Palgrave MacMillan, 217. https://doi.org/10.1057/9780230514447

\section{Copyrights}

Copyright for this article is retained by the author(s), with first publication rights granted to the journal.

This is an open-access article distributed under the terms and conditions of the Creative Commons Attribution license (http://creativecommons.org/licenses/by/4.0/). 